\title{
The Transmission of Household Objects from the National Socialist Era to the Present in Germany and Austria: A Local Conversation Within a Globalized Discourse
}

\author{
Chloe Paver ${ }^{1}$
}

Received: 29 September 2015/ Accepted: 30 December 2015/Published online: 5 February 2016 (C) The Author(s) 2016. This article is published with open access at Springerlink.com

\begin{abstract}
Increasingly, scholars of Holocaust memory stress its globalization: the ways in which the Holocaust has become a model or reference point for remembered events that belong to quite different historical and cultural contexts. The best of this literature acknowledges the ways in which the local, national, and global are in continual dialogue. This article looks at an instance in which memory remains stubbornly local and national even in contexts in which it is ostensibly internationalized. The article is concerned with history exhibitions about the Nazi era in Germany and Austria and examines one particular set of museum objects: household possessions that have been stored in homes since 1945 and that are typically presented by the museum as having "resurfaced" in the present. These objects are used to concretize abstract processes of remembering and forgetting, communication and silence, in the years from 1945 to the end of the twentieth century. As such, they form part of ongoing debates about how family memory operated during that period in Germany and Austria.
\end{abstract}

Keywords Germany - Austria · History museums · National Socialism · Nazis · Holocaust · Cultural memory · Jewish history · Material culture · Transmission · Heritage $\cdot$ Aryanization $\cdot$ Jewish refugees · History of Shanghai

\section{Introduction: Object Transmission in Contrasting National Contexts}

One of the final exhibits that visitors see on a tour of the Shanghai Jewish Refugees Museum (上海犹太难民纪念馆) is a rather careworn kitchen table with three wooden chairs. A heart-shaped hole is cut out of the centre of each chair's backrest, and the edges of the backrests have been carved into a series of curves and points.

Chloe Paver

c.paver@exeter.ac.uk

1 College of Humanities, University of Exeter, Queen's Building, The Queen's Drive,

Exeter, EX4 4QH, UK 
This folk-style furniture is unmistakeably alpine, redolent of mountain chalets, and inns. As rare material survivors from the 1930s, the table and chairs recall a historical period when many Jewish families undertook the long, often perilous journey to Shanghai to escape Nazi persecution (Stiftung Jüdisches Museum Berlin 2006). Since the refugees settled in only a few Chinese cities, foremost among them Shanghai, and since much more momentous events swept across China in the midtwentieth century, the furniture arguably evokes a local-rather than nationalhistory for China, though its European origins can nonetheless serve the aims of global diplomacy today, as will become clear below. By contrast, in Germany and Austria household goods from the 1930s have come to be seen as embodying a key national story, resulting in their increasingly widespread use in history exhibitions. Whether they originally belonged to Jewish or non-Jewish families, most of these museum objects are, like the Shanghai furniture, worth very little in monetary terms; instead, they embody stories of storage and retrieval that are understood to be paradigmatic for wider processes of cultural memory.

Through its display practices, which I analyse later in the article, the Shanghai Jewish Refugees Museum makes the Jewish furniture signify in a range of ways: its display celebrates Shanghai's stewardship of the table and chairs after the German Jewish owners left to start a new life elsewhere; it invites visitors to empathize with the emotional re-discovery of this lost family heritage in the present day; and, within the wider context of the museum, it presents the re-discovery of Jewish history in the cityscape as a catalyst for cultural exchange with Israel and other countries. Perhaps not surprisingly, the Shanghai museum's strategies of positivity and sentiment are not, by and large, open to German and Austrian exhibition-makers. The city of Shanghai can integrate the Jewish refugee experience into its presentday image as a metropolis open to the world. Thanks to the positive trajectory of the "lost-found" narrative it can also turn the neglect of decades to good account. Germany and Austria, on the other hand, cannot easily make a happy ending out of the resurfacing of material culture from the 1930s, remaining troubled both by the original events of Nazi rule and by the neglect of objects (and therefore, it is assumed, of historical responsibility) during the intervening seven decades.

The transmission through time of material culture is a key aspect of museums generally. Perhaps surprisingly, given how commonplace the term "transmission" (and, in German, "Überlieferung") is in literary studies, the English-language research literature on museums does not consistently use "transmission" for the passing of cultural artefacts from one generation to the next. Possibly this is because the word has been appropriated for use in an explanatory model of the communication process, according to which knowledge or ideas are "transmitted" by the museum to the museum visitor [see, for instance, Hooper-Greenhill, who critiques this model $(2006,362,367)$ ]. The transmission of material culture through time is evoked instead through related terms such as "preservation", "custodianship", "archiving", and "heritage". A search through Blackwell's Companion to Museum Studies demonstrates that where "transmission" is not being used to signify curator-to-visitor communication, it finds only occasional use, in discussions of the pre-museum age (Hoelscher 2006, 200), the early museum age (Abt 2006, 123), and non-Western museums (Kreps 2006, 458), suggesting that it is felt to articulate a basic underlying principle of museum work. 
When Kreps, for instance, writes that "cultural heritage preservation is defined as the transmission of culture through time" (Ibid.) she is implying, in context, that if Western curators would only recall to mind their fundamental task (transmitting culture through time), they would find that their work is not essentially different from-nor better than - that of non-Western custodians of cultural heritage.

While there would thus be no museums at all without material transmission, in the case of museum exhibitions about National Socialism object transmission is sometimes the very subject of the display. This is partly because the years 1933-1945 (1938-1945 in Austria) saw a quite unprecedented spate of confiscation, theft, and forced relocation of personal objects, so that objects have often taken convoluted routes into the present, in many cases as a result of historical persecution and profiteering (research is mostly regional, but for an overview, see Fritsche and Paulman 2014 or Dean et al. 2007); partly it is because, as historians and sociologists have become increasingly interested in family memory in Germany and Austria since 1945 (e.g. Neumann 1999; Welzer et al. 2002; Reiter 2006; Greiter 2014), so history museums have, in turn, become interested in objects that have been stored in the home and/or bequeathed to younger generations of a family. The significance of family memory for this cultural context is explained more fully below, but broadly speaking, it belongs to the secondary subject matter of the German and Austrian history museums that document National Socialism. While their primary focus is the historical events of 1933-1945, their secondary focus is the years from 1945 to the 1990s or what Reichel et al. (2009) term National Socialism's "second history". Depending on whether one takes a moral or a pragmatic point of view, during this post-war period Germany either failed pitifully to face up honestly to its past or it was never very likely, given the prevailing social circumstances, to address its past in a way that would satisfy left-liberal expectations. The present study aims to show how a subset of museum objects—objects kept in the home-play a role in this ongoing debate about how to read the years from 1945 to the end of the twentieth century.

Given the international nature of discourses about the Holocaust, it might be expected that Germany and Austria would narrate their stories of lost-and-found objects within an international framework. To a degree, that is indeed the case. In this article, however, I argue that even in avowedly international museums, the museum discourses surrounding objects preserved in the German or Austrian home can be surprisingly inward looking, a local conversation within a globalized discourse. This is, therefore, primarily an essay about transmission down the generations within a single culture, rather than about transmission across borders. Nevertheless, the cross-cultural literature on Holocaust memory, the efforts made by German and Austrian museums to internationalize, and the example from the Shanghai Jewish Refugees Museum already cited will all help to frame and define this monocultural experience in important ways.

\section{The Holocaust as Global Discourse}

Though it deals largely with memory practices other than museums, Huyssen's Present Pasts (2003) has been important for showing how the Holocaust has left its mark on discourses about other atrocities worldwide. Taking the example of the 
Memorial Park in Buenos Aires, which commemorates victims of the 1976-1983 Argentinian dictatorship, Huyssen argues, first, that evocations of the Holocaust served to strengthen the case within Argentina for addressing the dictatorial past and, secondly, that the design chosen for the memorial site has stylistic echoes of the Jewish Museum Berlin, as well as the Vietnam Veterans Memorial in Washington. For Huyssen, whatever might be the philosophical objections to comparisons between the Holocaust and other atrocities, in practice such comparisons help make memorial projects happen:

Holocaust commemoration [...] has functioned like a motor energizing the discourses of memory elsewhere. There is reason to wonder whether without the prominence of Holocaust memory since the 1980s, most of the memory discourses the world over would be what they are today. (Huyssen 2003, 99).

For this reason, Huyssen rejects Pierre Nora's approach in his Lieux de mémoire project, which is "fundamentally tied to the idea of national memory, whereas I am precisely interested in the ways in which global dimensions intersect with the national or the local in the construction of memory sites in the contemporary world" (97). Rothberg (2009) agrees with Huyssen that notwithstanding its supposed uniqueness, "the emergence of Holocaust memory on a global scale has contributed to the articulation of other histories" (6). Rothberg, however, takes a step further, arguing that Holocaust memory was itself shaped by other transnational memory discourses, pointing to "the more surprising and seldom acknowledged fact that public memory of the Holocaust emerged in relation to post-war events that seem at first to have little to do with it" (7). In particular, he sees the discourses of decolonization, notably in relation to Algeria, as having played a role in writings and discussions about the Holocaust in the early post-war period.

Other studies, while not necessarily demonstrating such globalizing processes at work, globalize the Holocaust by dint of comparative study. Williams (2007) proposes a new class of museum-the "memorial museum"-which deals with various kinds of "calamitous histories" (51), involving atrocities or mass death. The museums share certain features and functions whether the events happened in Poland, Cambodia, Bengal, Japan, or Rwanda. In a collection of essays by Gray and Oliver (2004) which uses "catastrophe" as its keyword, two chapters on memory of the Holocaust appear alongside studies of the memory of the Irish famine and of the massacre at My Lai. In their Introduction, Gray and Oliver observe "a gravitation towards the catastrophic" in studies of cultural memory, catalysed-not unproblematically, they argue-by the universalization or "totalization" of Holocaust discourse (3, 5-6). The new scholarly category of "difficult heritage" can likewise serve to bring diverse global calamities under one umbrella. In the collection of essays on difficult heritage edited by Logan and Reeves (2009), a chapter on Auschwitz-Birkenau (which the Introduction refers to as "a key genocide site" rather than as a unique genocide site (6)) joins chapters on sites as diverse as: the Maze prison in Northern Ireland; a site where Taiwanese "comfort women" were interned and raped; and China's Nanjing Massacre Memorial.

Writing at the same time as Logan and Reeves, Macdonald (2009) also centres her work around the term "difficult heritage", but, unlike Logan and Reeves, uses it 
in the service of a local study: of cultural memory in the city of Nuremberg. Building on arguments by Levy and Sznaider (2006) about an increasingly "deterritorialized" or "cosmopolitan" memory, she stresses that the globalizing tendency they identify is not intended to invalidate local research. On the contrary, research into local memory contexts is re-invigorated by an awareness of the interconnectedness of different geographical frames of reference, which are

simultaneously local and beyond local. That is, they involve specific local conditions and actors but these never act in a vacuum, even when they are actively producing "locality". Instead, [...] local actions are frequently negotiated through comparisons with other places, through concepts and ideas produced elsewhere and that may even have global circulation, and through the sense of being judged by others. (Macdonald 2009, 4)

Macdonald shows, for instance, that in Nuremberg, it has been local politicians who have sought, for local political reasons, to re-brand Nuremberg as a city representing universal human rights (Macdonald 2009, 127-132).

In her later work, Memorylands (2013), Macdonald offers a comparative study of cultural memory across the European nations, but cautions against an approach that would produce only generalizations; instead, she argues, researchers must pay attention to the local inflections that disrupt apparent patterns of similarity. Crucially, Macdonald sees these local inflections not in superficial manifestations of cultural diversity (differences in folk dances, say, or in food cultures) but rather in underlying modes of engagement with the past: "whether significance is attached to collective remembering at all, whether longer or shorter time periods are activated in local commemorative life or how personal and collective memories are brought together" $(2013,3)$.

\section{The Holocaust as Local Conversation}

This article poses similar questions in relation to Germany and Austria and their memories of National Socialism, asking how museums in these countries invoke and deploy ideas of local or national memory while simultaneously engaging with an internationalized discourse of Holocaust memory. My contention is that even while much research quite rightly focuses on the international and cross-cultural dimension of memory culture, and even while German history museums feature on the travel itineraries of many international tourists, including descendants of the victims, German and Austrian exhibition-makers continue, beneath this international hubbub, to conduct a quiet but distinctly audible German-German or Austrian-Austrian conversation about National Socialism.

A preliminary example taken from the Military History Museum of the Bundeswehr (Militärhistorisches Museum der Bundeswehr), situated in Dresden, is illuminating because transnationalism is inscribed rather explicitly on this museum, while the national and the local interact more discreetly in the displays. The MHM, as it styles itself, is an institution belonging to, and serving, the German national army (in token of which its Director is a military historian with the rank of colonel 
in the Bundeswehr). Yet it commissioned the globally active US architect Daniel Libeskind to re-configure its building so that it could house a new permanent exhibition. No sooner had the revamped and visibly internationalized museum opened its doors in 2011 than it was the subject of a transnational study. Arnold-de Simine (2013) sees the MHM as characteristic of a new brand of Western museum that generates empathy and/or nostalgia, asking non-involved spectators of history to adopt the pain of other groups or earlier generations, often through embodied, interactive experiences in the museum. She compares the MHM with the UK's Imperial War Museum North (housed in another Libeskind building) and with the Belgian museum In Flanders Field. Heckner, too (2014), has analysed the new MHM in international perspective, comparing it with the Museum of the History of Polish Jews in Warsaw.

Using an approach similar to Macdonald's, Arnold-de Simine identifies an interesting intersection between the international and the national at the MHM: she notes that the museum's decision not to invite visitors to identify with the national perspective of "their" soldiers is itself peculiarly German, an example of nonnationalistic patriotism known as "constitutional patriotism" or Verfassungspatriotismus (48-49). Her main focus, however, is on cross-cultural currents in European war museums, particularly their approaches to injury and trauma. In this, Arnold-de Simine responds explicitly_and critically - to the museum's self-declared anthropological approach to war, which strips war back to its basics under headings such as "Leiden am Krieg" ("Suffering in War") and "Formation der Körper" ("Disciplining Bodies") (85-86).

While this "thematic" route through the museum (the Themenparcours) provides the most relevant material for Arnold-de Simine's arguments, the museologically more conservative chronological route (the Chronologie) is in some ways more interesting. From this route, Arnold-de Simine selects another transnational exhibit, the shoes of Holocaust victims from Majdanek, arguing-by reference to Rothberg - that such "trauma icons" are used in museums worldwide, sometimes to address histories with no connection to the Holocaust (80-81). Arnold-de Simine's selection of the internationally iconic shoes may obscure the Chronologie's detailed historical exposition of the irreducibly German elements of Holocaust history: the persecution of targeted groups under National Socialism from 1933 onwards and the intersections between German war aims and the Holocaust. In the subsection dealing with 1933-1939 (that is, the period after the Nazis came to power but before the invasion of Poland), the guiding thread continues to be military history, including the militarization of society and preparation for war, yet the details about persecution and social exclusion (which in the 1930s were largely non-military, albeit sometimes para-military) exceed the military frame. Evidently, the museum's historians have made a conscious decision to tell the full story of the Holocaust and related crimes without allowing the remit of "military history" to set narrower boundaries to the narrative.

The MHM's children's display, which consists of "look-inside-me" cupboards spaced at intervals around the display floors, continues through the section on National Socialism and the Second World War. Each cupboard door is identified by a cartoon-style speech bubble, suggesting perhaps that the museum has chosen 
"talking points" for a school tour, and each bubble contains a simplified image, for instance an old-fashioned baby carriage for a display on motherhood under National Socialism. At the entrance to the section on 1933-1939, an icon shows three human figures, drawn in the pared-back style of lavatory-door signs (which means that, though ungendered, they appear male simply by virtue of not having a triangle for a skirt). Two of the three figures stand shoulder to shoulder; one of them points at the third, who stands apart, his back to the others and his head bowed. Clearly, the first two men are ganging up on the third. Yet, even if this image, with its echoes of religious instruction books, might appear to adopt a universalizing anthropological standpoint, presenting social exclusion as culturally non-specific behaviour, the information given inside the cupboard is historically and culturally specific, both in its historical reference to 1930s Germany and in its twenty-first-century cultural emphasis on local responsibility for National Socialist crime.

A first text gives information about the ways in which Jews were excluded from 1930s German society, initially through quasi-legal means, as a prelude to their forced emigration or their deportation and murder. Local actions and actors are identified as a key structural feature of the process, since local councils often passed anti-Jewish byelaws or instigated other discriminatory measures before these were required by national law or administration. This behaviour, on the one hand localized, on the other hand replicated across the nation, is picked up on in the second text which, as in other cupboards in the children's display, is accompanied by an exclamation mark and gives the young visitor a task or instruction. This second text addresses the young visitor in slightly different terms in the German original and its English translation:

Neben der Vielzahl von Sondergesetzen für Juden wurden auch bereits bestehende Regelungen gegenüber jüdischer Menschen besonders streng ausgelegt. In Berlin drohte Juden beispielsweise schon Haft im Konzentrationslager, wenn sie Straßen nicht exakt im rechten Winkel überquerten.

Wie oft hast Du schon eine rote Ampel übersehen oder bist einfach schräg über die Straße gelaufen? Hier kannst Du verschiedene Beispiele für die Ausgrenzung jüdischer Menschen im Alltag kennen lernen. Es ist nur eine kleine Auswahl. Das alles hat es auch in Deiner Stadt gegeben.

In addition to numerous special laws pertaining specifically at Jews, previously existing regulations were now more strictly interpreted in relation to Jewish people. In Berlin, for example, Jews were threatened with arrest in a concentration camp if they failed to cross the street at a precise right angle. How often have you overlooked a red light or simply crossed a street diagonally? Using the "snow globes" and your booklet, you can learn about different ways in which Jewish people were excluded from everyday life. Examples of this could be found in every German city.

One could quibble with the Holocaust pedagogy employed here, given that the rule about crossing the road at a right angle, however shocking, is not typical of the many more banal assaults, both petty and grave, material and psychological, on Jewish life and livelihoods during the 1930s. Are the most quirky or sensational manifestations of exclusionary practices, one might ask, really the best starting point 
for understanding the beginnings of the Holocaust, or would it be better to start from the more regular restrictions, both minor and major, which affected most Jewish lives? My main interest, however, lies with the translation, and in particular with the statement "Examples of this could be found in every German city". This is an adaptation of the original sentence, for which a more literal translation would be: "All this happened in your home town, too". Though it may seem trivial, the German sentence is emblematic of much museum discourse in Germany and Austria today, which addresses itself, implicitly or explicitly, to a local audience and tells them: "This happened in your home town".

Summarizing work by Mads Daugbjerg on a Danish national memory site, Macdonald (2013, 206-208) notes that even an avowedly post-heroic war museum -one that attempts to view war from the dual perspective of the opposing armiescan unconsciously reaffirm the national, for instance if visitors hear a patriotic tune played as background music and then whistle it as they walk around the site. "The nation", concludes Macdonald, "is difficult to dislodge as it is subtly reasserted in banal interactions" $(2013,207)$. In its context, the word "banal" refers to Michael Billig's work on "banal nationalism", in particular Billig's observation that the linguistic indicators known collectively as "deixis", that is, words whose meaning is relative to position, can place readers within a national space by indicating what is "our" and what is "here". Linguists speak of "person deixis" (generally encoded in pronouns such as "I" and "they"), "place deixis" (encoded in words designating the "here" or "there") and "time deixis" (encoded in words which specify the "now" or "then").

Following Macdonald's method, we can bring together Daugbjerg's case study and Billig's terminology in analysing this text at the MHM, though here, unlike in Daugbjerg's example, it is not a case of an avowedly "non-national" museum accidentally leaving cracks through which positive national identifications can seep back in. Rather, an avowedly "non-national" museum promotes local soul-searching as a national virtue and duty. At the indisputably cosmopolitan Dresden museum, person and place deixis combine in the phrase "in deiner Heimatstadt" ("in your home town") to "reassert" the national-through an insistence on the local. The time deixis does not need stating since it is constituted by the presence of the reader in front of the display, and since those addressed in German will always be Germans whose home towns were sites of prejudice and persecution, but it is invoked indirectly in the invitation to the young reader to imagine all the times they have walked across the road in their lives so far. By this means, they are encouraged to envisage the democratic streetscape in which they spend their lives as a place of freedom, and to imagine_-bodily_an alienating, non-democratic "other".

Linguistics identifies a further category of deixis, "social deixis", expressed notably in the so-called $\mathrm{t}-\mathrm{v}$ distinction: the distinction between formal and informal second-person pronouns in some languages. By convention, museums in the German-speaking countries address adult visitors as "Sie" and young visitors as "du". The "du" is thus obligatory for the children's display. Nevertheless, partly thanks to its capitalization, which is a signal of direct address, the "Du" reinforces a communicative act in which the children of Germany are exhorted to acknowledge 
that their localities have a history not just of enacting persecution in obedience to state directives but of willingly initiating persecution.

So far I have followed Macdonald in applying the linguistic term "deixis" to the analysis of national discourse written in the national language, in the setting of the museum; but it happens that deixis is also central to the practice of translation because this feature (particularly, but not only, place deixis) must be routinely adjusted in the transfer from one language to the other. The MHM's translator has correctly adjusted the place deixis for a non-German visitor: the "Heimatstadt" ("here") becomes a "German city" ("there"). But the translator deals unevenly with the person deixis. At the first instance of its use, the translator continues to address the question about crossing the road to "you", even though the "you" in question has changed with the language, as well as broadening out to include adults, given the lack of $\mathrm{t}-\mathrm{v}$ distinction in English. In the second instance, the translator omits all reference to person, rather than adjusting the person deixis from second to third person; he or she does not write: "Examples of this could be found in the home towns of all young Germans who visit this museum". Wittingly or unwittingly, the translator envisages an international audience that can reflect on what a non-democratic society is like and contrast it with their own. However, the translator leaves no trace of the German-German, adult-child conversation being conducted in the original, something to which only bilingual visitors have access.

Of the dozens of exhibitions about National Socialism in a local or regional setting that are shown every year across Germany and Austria, nearly all are monolingual (sometimes leading to requests from tourists, in the visitors" books, for translations). The presence or absence of translations in exhibitions about National Socialism is therefore one indicator of the intended range of communication, though the example of the MHM suggests that it is a more complex and less reliable indicator than Arnold-de Simine implies when she writes that "The use of language [at the MHM and two other museums] not only reflects how many international visitors are expected to come but is also a signal of who may find themselves represented there" (Arnold-de Simine 2013, 77). The MHM example suggests that "representation" is not a necessary consequence of translation, since the translation quoted above excludes overseas visitors from a conversation which has no part for them. The MHM numbers among a small group of large-scale museums that can afford to pay for translation throughout its displays, helping it to a share of the international tourist trade in Dresden, but this text for children has reached an uneasy compromise between cultural mediation and cultural separation. This may confirm Aleida Assmann's observation that Holocaust educators in Germany, particularly those working at museums, do not necessarily welcome the internationalization of Holocaust memory and of Holocaust education practices. Some insist on the importance of positioning the Holocaust within German national history and of deploying pedagogical strategies which respond to the national context (Assmann 2010b, 100-101). A more literal translation of a text at another museum, discussed later in the article, casts further light on this issue. 


\section{Household or House-Bound Objects and Family Memory}

German and Austrian history museums have a marked interest in mobile objects, particularly in the object odysseys caused by the forced migration of Jews and other victims of National Socialism. The exhibition "Home and Exile" ("Heimat und Exil"), staged at the Jewish Museum Berlin in 2006, showed, among many such objects, an English vocabulary primer which prepared a Jewish German family for a new life in cosmopolitan Shanghai (Stiftung Jüdisches Museum Berlin 2006, 131). Until at least 2006, the main exhibition of the same museum showed welding equipment taken back to Germany from Shanghai after the exiled owner had learned a new trade there. This article, however, is not concerned with the hundreds of thousands of such objects that left Germany or came back, but rather with the objects that stayed at home, quite literally in the German home, transmitted within German families from the National Socialist era down to the present day.

These objects are of particular interest to history museums because they can be used to make concrete and visible the otherwise abstract processes of remembering and forgetting that characterize roughly the half century from 1945 to 1995 . In fact, "remembering and forgetting" is a rather outdated, though still convenient shorthand for what went on in this period. The long-prevalent academic and cultural paradigm was one of "forgetting until forced to remember": the 1950s and 1960s were characterized as years of "silence", "repression", and "amnesia", with the majority of Germans and Austrians wanting to put the past behind them, and this national silence was, it was claimed, only broken by a hard-fought counter-struggle to bring the past to light which finally began to gain the upper hand from the 1970s onwards (in Austria from the 1980s). Sociologist Margit Reiter's suggestion that there was an element of self-reinforcement in this model-that those who wanted to present themselves as critics of the supposed post-war silence about National Socialism repeatedly invoked that silence-is plausible (Reiter 2006, 47). Her study of the effects of National Socialism on post-war generations, based on interviews with older Austrians, is typical of the rather more nuanced approach taken by much recent scholarship, which shows that silence was only one, partial response to the National Socialist past within families and friendship groups of the non-persecuted majority, even if the stories they did tell generally centred on their own personal joys, sorrows, and losses rather than on the suffering of those targeted by the regime. Reiter sees "silence" or "unspoken words" ("Schweigen") as a linguistic commonplace that is trotted out on cue by her interviewees even as the same interviewees readily offer evidence to the contrary:

Tatsächlich beklagt beinahe jede/r "Nachgeborene"-so auch der Großteil meiner InterviewpartnerInnen-in geradezu stereotypen Worten, dass in der eigenen Familie "immer nur geschwiegen", "nie darüber geredet" oder "nichts erzählt" worden sei. Trotz solcher Beteuerungen werden im Anschluss oft sehr wohl Fakten, Details und Geschichten weitererzählt, die-auf meine Nachfrage hin-auf Erzählungen in der Familie zurückgeführt werden. (Reiter 2006, 47) 
Almost everybody who was born after the end of the Second World Warincluding the majority of those I interviewed-uses positively stereotypical formulations to bemoan the fact that in their family "there was always complete silence" or "nobody talked about it" or "nobody told stories about it". Yet after making such claims they often go on to recount facts, details, and stories which-when I ask where they come from-they say are based on stories told within the family. [Author's translation]

One way in which Reiter tries to move beyond the "silence" model is by arguing that speech is the prime, but not the only means of communication within a family. Elements of the past may be acted out in non-verbal behaviours and attitudes, and, importantly for my analysis, they may continue to be present in the house in the form of objects: "Oft stießen die NS-Nachkommen in ihrem Zuhause auch auf NSÜberreste in Form von NS-Orden, NS-Dokumenten oder einschlägiger NS-Literatur im elterlichen Bücherschrank, darunter nicht selten auch Mein Kampf von Adolf Hitler" ["Children of those involved in the National Socialist era often stumbled across remnants of that time in their homes. These could be National Socialist medals or documents, or National Socialist literature in their parents" bookshelves, including, not infrequently, Adolf Hitler's Mein Kampf'”. (Reiter 2006, 73. Author's translation).

While Reiter thus takes a more objective look at communication within the family home after 1945, her study is not entirely neutral. Not unreasonably, she is critical of the less liberal or unreconstructed views of those she cites. Some of the parents and grandparents of her interviewees, that is, the generation that were adults during the National Socialist era, "geben [Geschichten] zum Besten" (regale others with what they consider to be entertaining stories), "strapazieren die Opferversion" (trot out the tired old story about Austrians being victims) or "schwelgen in vergangenem Heldentum" (wallow in past heroism) $(51,56)$. The tone of Reiter's language chimes with something that historian Alon Confino writes at about the same time as Reiter. He agrees that "silence" must be re-thought but also puts scholarly views of the unrepentant post-war majority in the frame:

The previously common argument in historical literature that the Germans kept the Nazi past hermetically sealed and silenced does not stand up to historical evidence. We may not like everything that Germans had to say about their experiences during National Socialism, but they were not silent about them (Confino 2006, 219-220).

While Confino's catchy formulation, in this last sentence, may run the risk of overstating the talkativeness of post-war Germans-given that there is plenty of evidence of very real silences, in response to both trauma and taboo (e.g. Reiter 2006, 61-63) - it reminds us again that the picture was more mixed than the "Totschweigen" ("hushing up") generally applied as a blanket term to the early post-war period and that "we" (by which he presumably means academics) should not be prevented by our distaste from looking honestly at post-1945 communications. 
In her study of family memory in recent German fiction and film, Anne Fuchs cites another of Confino's exhortations to re-think the 1950s and 1960s: "Rather than asking why Germans did not remember their criminal past, a better question would be what in fact they did remember of National Socialism" (Fuchs 2008, 15, citing Confino 2006, 237). Fuchs uses Confino to support her argument that a moralizing view of post-war Germans has, for too long, obscured both the social usefulness of amnesty (or what Hermann Lübbe, using an appropriately verbal term, termed "discretion" (Fuchs 2008, 15)) in the transition to democracy and the real ways-however morally disappointing they might have been-in which people related to their pasts. One might add that even where Germans and Austrians genuinely endeavoured to forget what they knew about the crimes and wrongs of National Socialism, forgetting is an act that it is logically impossible to will (as Esposito $(2010,181)$ points out) and is therefore likely to have alternated with moments or periods of remembering.

Although this discussion of silence and talk has brought the argument back again to words, it is precisely because silences, mentalities, and the oral tradition are non-material that history museums - which would struggle to function without material culture-have become increasingly interested in showing Nazi-era objects from the German family home, often in the storage containers in which they were kept after 1945. In nearly every other museum context, objects would be taken out of their containers for display, containers being contingent and peripheral, secondary to the object itself. In this case, however, typical containers on display include purpose-built ones such as trunks and suitcases or re-purposed ones such as cardboard boxes and biscuit tins. Not many exhibitions go as far as "The Burden of Images: Franconia under National Socialism" ("Bilderlast. Franken im Nationalsozialismus"), held in 2012 at the Documentation Centre of the Nazi Party Rally Grounds (Dokumentationszentrum Reichsparteitagsgelände), which mocked up a complete attic room to display the Nazi memorabilia that local people regularly bring to the museum, but many exhibitions try to evoke the idea that, after 1945, people held on to objects, often long after they ceased to be useful, keeping them in the liminal spaces of the house where they remained suspended between use and disposal.

At the end of its account of clothing and textiles in the National Socialist era, the temporary exhibition "Glamour and Horror" ("Glanz und Grauen"), staged by the LVR-Industriemuseum Ratingen in 2012, briefly turned its attention to the post-war era. An information board explained that in 1945, when loyalty to the regime was suddenly no longer an asset, Germans were careful to de-Nazify their clothes and belongings. At the same time, however, a serious textile shortage made it necessary to recycle wherever possible. The exhibition-makers were therefore careful not to automatically equate material continuity after 1945 with a reprehensible continuity of mindset, though they allowed that as a possibility. The board also evoked the receptacles in which Germans, whether motivated by continuing political loyalties or just by thrift and want, kept the material remnants of their engagement with Nazism. Having removed any such objects from public sight, said the information board, people 
verteilten sie sorgfältig auf unterschiedliche Behältnisse: die Knöpfe in die Knopfschachtel, die Hüte in die Karnevalskiste, Parteiabzeichen ins Schmuckkästchen... Orte, an denen sie gerade in unseren Tagen wieder auftauchen.

distributed them among various containers, putting buttons in the button box, hats in the dressing-up box, party badges in the jewellery box ... places where they continue to turn up today. [Author's translation]

In the longer catalogue text from which this information board has been summarized, curator Claudia Gottfried includes a fourth storage space: "die Abzeichen und Orden in den Schreibtisch" ("badges and medals in the writing desk"; Gottfried 2012, 77). In the display case that accompanied the text, the exhibition-makers showed brown and white buttons threaded with string to keep them together. Alongside them were offcuts of red, black, and white material tied in a bundle by another remnant of cloth. Although the exhibition-makers did not display the objects in the containers in which they were kept between 1945 and the 2010s, they used the captions to evoke those containers: the buttons, from a uniform of the National Socialist girls' brigade, the BDM, had been kept in a button box since 1945 and the pieces of material (cut from a swastika flag) had been kept in a box containing odds and ends of material (a Stoffrestekiste).

In the title of her contribution to the catalogue (which was the title also of this final exhibition section), Gottfried uses vocabulary reminiscent of the "repression" paradigm which is now considered an oversimplification: "Vergraben, versteckt, verdrängt" ("Buried, hidden, repressed"). However, like Reiter, she and her exhibition team conducted extensive interviews with elderly people who lived through the 1930s and 1940s, so that the essay is closer to Reiter and Confino than its title suggests, even if Gottfried does not draw out all the implications of the domestic storage she describes. For while it may be impossible in retrospect to establish what individual motivations led to the buttons and material being kept, their owners clearly did not choose the kind of permanent disposal implied by the metaphor of "burial" nor even the less definitive, but similarly out-of-mind disposal implied by the metaphor of "hiding away". On the contrary, they would have been reminded of the 1930s and 1940s whenever they sewed, just as the owners of the hats, medals, and badges would have stumbled over the past periodically when the dressing-up chest, writing desk, or jewellery box were opened. As Reiter suggests, such objects would necessarily have constituted one element in family communication, verbal or non-verbal.

Gottfried's final comment ("places where they continue to turn up today") indicates the value of these storage habits to museum curators (a point to which I return later). Gottfried is mostly interested in why younger generations, having found such objects when clearing out a parent's or relative's house, then bring them to the museum. Their motivations, she tells us, range from horror that their family were involved in National Socialism, to a belief that by taking them to a museum they are contributing to the education of the young, to a fear that they will otherwise be monetized as flea market products. 
Despite covering many of the same topics as "Glamour and Horror" and despite using oral history sources in a similar way, the Imperial War Museum's 2015 exhibition "Fashion on the Ration" made no reference to the fate of 1940s clothing and cloth during the years from 1945 to the present day, let alone to the containers in which any surviving materials were kept or to the thoughts of those who inherited these containers and passed them on to the museum. Nor did the accompanying book (Summers 2015). Though the final section of the exhibition was devoted to the "legacies" of wartime fashion, what was meant were legacies in the fashion industry; the continuing material presence of wartime in family homes was not addressed. Just as National Socialism has had a "second history" in the successor states of the Third Reich since 1945, so, too, has the Second World War had a "second history" in the UK, yet there is evidently no very urgent imperative to reflect on that afterlife in history exhibitions.

\section{Jewish Objects in the Non-Jewish Home}

While the examples discussed so far represent the personal mementoes of members of the non-persecuted majority of Germans and Austrians, some non-Jewish German and Austrian homes have also been the vessels of transmission for Jewishowned objects that were acquired, often legally if not morally, during the time when local Jews were being forced from their homes, ahead of either emigration or deportation. The background to such local acquisitions is the state-sponsored process known as "Aryanization" (“Arisierung"), by which Jews were systematically stripped of their wealth, homes, livelihoods, and belongings in the course of the 1930s. While art theft has received most attention outside Germany and Austria, questions about what happened to ordinary household objects remain a more closed concern of Germans and Austrians, generally researched at local level (e.g. Haerendel 2004; Meinl and Zwilling 2004, 141-152, 167-168). Whereas nonJewish objects from the 1930s and 1940s are often displayed by history museums in their storage boxes, the point that exhibition-makers wish to make about misappropriated Jewish possessions is often that they were in use throughout their time in the non-Jewish home. The Jewish Museum of Franconia in Schnaittach (Jüdisches Museum Franken in Schnaittach) is housed in the former synagogue and rabbi's house. These buildings were saved from the November Pogrom of 1938 only because the director of the local history museum wanted them to house his collection in. Shorn of their Jewish contents and attributes, the buildings served this purpose for the rest of the twentieth century, until a Jewish Museum was established. On entering the more or less empty main room of the synagogue, the visitor sees two chandeliers that hung there until the director of the Heimatmuseum took them down and sold them, shortly after the November pogrom. Rather than restoring them to their original position on the ceiling, which would hide the fact of their theft (and also the continued absence of their companion chandeliers), the museum has mounted them inside two glass frames resting on the ground. This highlights both their removal from their proper place and their redundancy now that there is no Jewish community to use the synagogue. 
The caption tells the visitor matter-of-factly that right up until they were handed over to the newly founded Jewish Museum, the chandeliers were used as light fittings in the sitting room of a local non-Jewish family. Although the caption does not spell it out, this display contributes to the more nuanced understanding of the post-war period advocated by Reiter and Confino in the sense that it switches focus from a blanket condemnation of supposed German forgetfulness after 1945 to a consideration of what ordinary Germans did remember. Evidently, the knowledge that these were chandeliers from the synagogue survived for over 50 years in the family; otherwise, family members would not have chosen to dismount them from the sitting-room ceiling and "return" them to the museum in the 1990s. It therefore seems unlikely that there was much forgetting going on in this particular non-Jewish home, which was positively illuminated by an understanding of the harassment, dispossession, and deportation of local Jews. In this example of a museum display, then, understanding the complex coexistence, in the post-1945 family home, of incentives to forget and prompts to memory does not necessarily lead to a more forgiving view of German family memory. Rather, the established critical view of a populace that forgot shifts only slightly to a revised critical view of a populace that remembered but drew the wrong consequences from memory. In this case, a family remembered local persecution clearly and yet used the synagogue chandeliers for 50 years before coming to the view that this might not be appropriate.

Where they were not in use, objects of Jewish origin, like the cast-offs from National Socialist material culture, remained stored and unattended to, in liminal, rarely used spaces within the house. This was often the case with objects taken into safekeeping by neighbours of Jews, who kept hold of them in the expectation that the Jewish owners or their relatives might return to retrieve them. In theory, such objects make it possible to present positive behaviours from the 1930s: actions that, while stopping well short of resistance, show a willingness to extend a favour to a Jewish neighbour in defiance of vicious anti-Semitic propaganda and anti-Jewish policies. In practice, however, museums indicate a range of possible motivations for such actions, and such objects can even play a fairly conventional role in the condemnation of 1930s anti-Semitism and of post-war indifference to the fate of Jews in the Holocaust.

Michael Verhoeven's documentary film about Aryanization, Menschliches Versagen (2008) addresses the role of the museum only peripherally, but with reference to precisely this kind of object. Rather like the feature film with which he made his name, The Nasty Girl (Das Schreckliche Mädchen 1990), Menschliches Versagen presents Aryanization as a secret that was wilfully suppressed by the postwar authorities for 60 years (an extension of the 30 years of the earlier film), and only brought to light thanks to academic obstinacy. Though largely a montage of talking heads and documentary evidence, the film is framed by opening and closing sequences involving an object that has passed from Jewish to non-Jewish ownership and back again. Clearly filmed in the present day, the opening sequence shows a large travel trunk being carried up a set of stairs by three people, filmed from above to emphasize the unwieldiness of the object. A few viewers might recognize the stairs as belonging to the Jewish Museum Munich (Jüdisches Museum München); 
others must wait until the final $5 \mathrm{~min}$ of the film to find out the significance of the scene.

There, we learn that the trunk and its contents were entrusted to a non-Jewish German couple by Jewish friends. Troubled by his family's continued possession of the trunk, the grandson, Hubert Engelbrecht, brought it to the Jewish museum, which duly traced a descendent of the original owner. Since this descendent, Christiane Picard, has already been one of the talking heads, we know her family's story: that her father had his licence to practise medicine withdrawn and that her grandfather committed suicide rather than be interrogated. Verhoeven cuts between Picard and Engelbrecht, both of whom are filmed with the trunk also in frame. Engelbrecht stands next to it, while Picard reconstructs the moment when she pulled the museum's protective cover off the trunk and opened it for the first time. Thus, the film, unlike a museum whose objects are behind glass, can dramatize the way in which individuals experience the materiality of an object affectively, as a bridge to the past. In the voiceover to the reconstructed scene, Picard remembers her curiosity about "all the kinds of things that might be inside" ("was war da wohl alles drin"), but the visuals show her exposing the empty interior of the trunk. Verhoeven thus deprives his viewer of a resolution in which personal objects allow her to reconnect with her family, while giving any viewer critical of Germany's post-war failings a satisfying "reveal": the neighbours did not, of course, preserve the contents.

In his speeches to camera, Engelbrecht uses a word that is conventional for this context: "totgeschwiegen" ("hushed up", "kept quiet"). In context, he is speaking about his mother not asking him why he has removed the trunk from the house, but the loose phrasing and lack of directorial comment allow the words to stand for a more general generational silence. Engelbrecht cites two classic liminal storage places for the object: as a child he played with it in the attic and recently, having plucked up the courage to take it to the museum, he retrieved it from the Stadel or hayloft. In both these places (which may well be one and the same), the object is simultaneously present and absent to the family that kept it from 1938 to 2001 and that passed on knowledge of its origins to two further generations. "Forgetting" would certainly be an ill-fitting word to use of this situation.

Engelbrecht claims that as a child he found stacks of share certificates beside the trunk, while Picard is filmed reading from a letter written by Engelbrecht's mother, who wants a chance to explain her side of the story. Both Engelbrecht and Picard are sceptical of the mother's suggestion that the trunk contained nothing valuable on its arrival at her parents' house (or that such valuables as there were had to be given to the removals firm as a fee). Finally, Engelbrecht speaks of family rumours that his parents stole valuables from the trunk. This is almost the last statement in the film: Verhoeven cuts in one more sequence involving an American contributor to the documentary, who says that she had always wondered what happened to the belongings of the deported, but now "This is the answer". The pronoun "this" probably relates to records of an auction of her husband's grandparents' belongings which she was shown responding to earlier in the film; certainly, by "this" she did not mean Engelbrecht's comments about his family. Nonetheless, the juxtaposition of her final words with his has the effect of supporting his suspicions that theft was involved. 
While thus possibly a little manipulative, the documentary exposes, in a way that museums tend to avoid, the inter-generational conflicts that may delay but eventually facilitate the restitution, or at least de-privatization, of Jewish objects. While individuals may have complex emotions (including shame) invested in objects before they are surrendered to the museum, on the whole those emotions are left at the museum door, in the sense that they are edited out of any exhibition. The travelling exhibition "Legalised Theft" ("Legalisierter Raub"), which has been running in the state of Hessen since 2002, exemplifies this. At each new village or town where it is to be held, the exhibition-makers put out a public call for Jewish objects still in non-Jewish homes, advertising in local newspapers and online (e.g. Gedenkstätte KZ-Osthofen 2013). The text of this call offers local people the mediation of a Catholic or Lutheran priest if they feel unable to contact the exhibition-makers directly about the objects still in their home. The shame felt in relation to objects is thus a potential obstacle in the way of making the exhibition, but it is not the exhibition's subject matter: indeed, if a local person donates an object, the exhibition-makers sometimes have to agree that they will mitigate the donor's shame by not revealing family names in the exhibition (author's discussion with an exhibition-maker, 2013).

Conversely, the Jewish Museum of Hohenems attempts to provoke explicit discussion of this shame, not just in its catalogue (in which a commissioned short story tells of a silver spoon that haunts the laundry room of a non-Jewish home (Köhlmeier 2008)), but also in its exhibition display. It happens that this small museum is particularly international: the town sits at the point where Austria, Germany, and Switzerland meet; it was a transit point for those escaping the Nazi regime clandestinely once emigration was no longer legal and also a transit point for displaced Jews after 1945; today the museum prides itself on being a meeting point for the worldwide diaspora of descendants of former Hohenems Jews.

The museum combines conventional object displays with quotations printed on the windows. One such quotation, from an elderly Jewish woman who once lived in Hohenems, concerns objects at the point of transition from the home to the museum: "Jetzt muss ich Sie aber etwas fragen. Mit was kann man in Vorarlberg ein jüdisches Museum einrichten? Da müssen die Leute ja im Dunkeln das Zeug bringen". Since the quotation also prefaces the catalogue, standing as a kind of motto for the museum, it is translated in the English-language version of the catalogue: "Now I have to ask you something. With what do you want to install a Jewish museum in Vorarlberg? The people there have to bring the stuff in the dark". Clearly something has got lost in translation, and it might be better translated as: "But let me ask you something: What do you imagine you are going to use as the basis for a Jewish museum in Vorarlberg? People would have to bring things in the dark". Even this improved translation is likely to make little sense to the average English speaker, begging the questions: "What people? What things? What do you mean, 'in the dark'?'.

The German director of the museum, Hanno Loewy, is fond of a laconic style: in his published writings, too, he presents the reader with telling statements from third parties whose significance is not elucidated (for instance Loewy 2012, which is interesting for its accounts of people hesitating to donate objects to the museum). In 
that sense, it is in keeping with a certain "house style" that the quotation on the window does not spell out its meaning: namely that some local people still have Jewish objects in their possession as a result of the dispossession of the Jews in the 1930s and that they or their descendants would, in the view of a survivor, be too ashamed to donate them openly to a museum because that would mean admitting responsibility publicly, in front of their neighbours, for past events that they are not ready to face up to. The implied reader of the window quotation, in its German form, is an audience of the initiated who are able to enjoy not needing to be told exactly what local nerve the quotation is touching or who are perhaps relieved that the museum is sparing their feelings by not being explicit. The English translation performs the same communicative act, but the message is unlikely to arrive at its destination intact. Here, once again, the international and local intersect rather awkwardly.

\section{Return to Shanghai}

Before concluding, I want to use a more detailed analysis of the scratched and scuffed table and chairs on display at the Shanghai Jewish Refugees Museum to advance two more arguments: one concerning the "lost-found" narrative embodied in rediscovered or reappearing objects from the 1930s and one about Jewish participation in German and Austrian folk culture.

The display of chalet-style furniture is captioned in English: "This is the furniture used by the family of Mr Duldner Kurt when they took refuge in Shanghai". Beside the table, one of the two video clips showing on a video screen is captioned: "An old man burst into tears when he saw the chairs and furniture he had used when he was in Shanghai". As I indicated in the introduction, in the Chinese context it is possible to celebrate both the original offer of refuge by the city of Shanghai and the preservation of Jewish material heritage after the dispersal of the Jewish community post-1945. The old man-presumably Kurt Duldner, visiting Shanghai after many decades-may burst into tears, but it is implied that these are tears of joy because the people of Shanghai have reunited him with material traces of his past. In this context, the fact that Shanghai was for decades indifferent to the memory of this particular wave of twentieth-century immigration is not a negative factor, constituting as it does the necessary prerequisite for the positive story of rediscovery. This impression is strengthened in the courtyard of the museum where several shop fronts from Jewish businesses have been reconstructed. The businesses were established in the early twentieth century in an area known as "Little Vienna" and their frontages were found during an urban regeneration project in 2008, when later Chinese shop fronts were removed. Photographs on a display wall show the moment of discovery. In a sign that the local and the international intersected in interesting ways even in the 1930s, when Austrian exiles were establishing a homefrom-home in Shanghai, the café "Würstl-Tenor" calls itself a "Wurst- u. Sandwichs-Stube" and another café goes by the name "Atlantic" (an ocean not known for lapping at the edges of either Germany or Austria). The name "Café Atlantic" has been passed on to the museum's courtyard café and two of the café's 
plastic rattan chairs bear plaques to mark the exact spot where Benjamin Netanyahu and his wife Sara sat during the opening ceremony for the courtyard display in 2013. The discovery of palimpsestic traces in the urban environment has thus been made to serve positive diplomatic aims [here in relation to Israel but in other contexts, as is clear from news items at the website, in connection with Germany, Austria, Poland, Hungary and the US (Shanghai Jewish Refugees Museum 2014)].

While it is a statement of the perfectly obvious that a history that is "dark heritage" for Germany and Austria (because the Nazi regime instigated a genocide) is positive heritage for China (because-for a lucky few-it offered sanctuary from that same genocide), what is nonetheless worth underlining is how this affects narratives of the period from 1945 to the turn of the new millennium, the "second history" of National Socialism that has been the focus of this article. Objects were lost and found (or stored and retrieved) in Germany, Austria, and China in broadly comparable circumstances: in both Europe and China, the dispersal of the Jewish community in the wake of the genocide allowed a historical period to be forgotten, leaving orphan objects to survive unnoticed in the household and the streetscape. While the Shanghai museum may declare this forgetting regrettable, it sowed the seeds of a re-discovery that is now cause for celebration. Conversely, in Germany and Austria, post-1945 neglect (even in the form of neglecting to get rid of things) is understood as a secondary shame or as a continuation of the attitudes that allowed the Holocaust to happen. At best - in some academic research literature though not, to my knowledge, in the 200 or so history exhibitions I have visited-it is considered a necessary evil that fostered social reintegration and recovery after a deeply divisive experience of dictatorship.

At the same time, it would be simplistic to assume that only Chinese exhibitionmakers can enjoy the positive rewards of the lost-and-found narrative. It has to be taken into account both that exhibitions are particularly open to interpretation by the visitor (who will inevitably apply habits and paradigms from their experiences outside the museum to exhibitions about National Socialism) and also that exhibitions are milestones in professional careers which rely, to a lesser or greater degree, on "finds". In 2013, the NS-Documentation Centre of the City of Cologne (NS-Dokumentationszentrum der Stadt Köln) based an exhibition about the life of a Jewish emigrée around the hat box in which she kept papers from her German past: "A Whole Life in a Hatbox: Bertha Sander, a Jewish Interior Designer from Cologne" ("Ein ganzes Leben in einer Hutschachtel. Bertha Sander: Eine jüdische Innenarchitektin aus Köln"). The hatbox and its contents present us with a third category of objects, alongside remnants of the National Socialist era and Jewishowned objects in the non-Jewish home: objects that Jewish survivors kept from their former lives. The centrality of the memory container to the exhibition's message is highlighted not only by the use of the hatbox in the title but also by its prominent display at the exhibition (despite the fact that the box was evidently only one of the routes by which Bertha Sander's life was transmitted to the present). As photos from the exhibition show, the hat box hung, open-lidded, from the ceiling at the beginning of the parcours and a spotlight gave the otherwise modest object a largerthan-life shadow on the wall behind (NS-Dokumentationszentrum der Stadt Köln 2013). Judging by its website, the exhibition stressed Bertha Sander's talent as an 
interior designer, her cosmopolitan outlook, and the lack of opportunity for her to pick up her career in exile in London, a disappointment which left her embittered in old age. In this way, the museum insisted on the crucial distinction between Holocaust survival and success, forcing visitors to confront the psychological after effects of exile. The contents of the hatbox contained the promise of a future life that could not now be lived and their storage for so long in the hatbox spoke of their suspension from use and eventual redundancy, not, as is often the case with memory containers, of the pleasurable treasuring of mementoes. Even so, the hatbox arguably offset the harsh realism of the exhibition with the comfortable fantasy of the historical treasure trove hidden in the domestic sphere, awaiting discovery, a fantasy made more appealing by the nostalgic associations of hatboxes, as objects for which society no longer has a use. In an accompanying book, the co-curator of the exhibition, Ulla Rogalski, was able to make her fortuitous discovery of the hatbox (and of other boxes that were stored in attics and sheds) into an entertaining story (Rogalski 2014). The title "A Whole Life in a Hatbox" also makes the hatbox a neat double for the museum, since it encapsulates a life in miniature just as all museums compress lives into a highly condensed narrative and material form.

While not all trunks, cardboard boxes, albums, or envelopes found in German and Austrian homes are as aesthetically satisfying as Bertha Sander's hatbox, and while many of the objects discussed here appear without their containers (and therefore without the allusion to the thrill of opening a magic door onto the past), nevertheless even those retrieved objects, such as the brass chandeliers at the Jewish Museum Schnaittach, whose stories are most obviously an indictment of their temporary owners, may evoke, consciously or unconsciously, a pleasurable feeling of the long-hidden but rediscovered treasure. In such cases, the non-Jewish German home takes on a paradoxical character: it serves a valuable role, from today's museological perspective, as a preserver of rare traces of Jewish life even though in the past it was a site where people wrongly asserted ownership over misappropriated Jewish possessions. This complex effect is hinted at in the title of another exhibition at the documentation centre in Cologne. "Fundstücke" ("Finds"), available today in an online version (NS-Dokumentationszentrum der Stadt Köln 2001), told the story of the museum's latest acquisitions. The word "Fundstücke" denotes both soberly academic archaeological "finds" and "finds" in the sense of "unexpected treasures" of the kind one might find at a car-boot sale or in a junk shop. Some of the acquisitions had been found in just those kinds of serendipitous circumstances, and others in the family home; but all of them were, from the perspective a museum trying to document a neglected area of regional history, what English would call "real finds".

A small local exhibition called "What Remains: A Family History in a Cardboard Box" ("Was bleibt. Eine Familiengeschichte im Karton", at the Synagoge Memmelsdorf in 2006) put the eponymous box, a rather battered old packing box for Persil washing powder, on display in a glass case, alongside the valuables (silverware and china) that a Jewish neighbour had placed in it for safekeeping. The shabbiness of the cardboard box and the dated Persil logo (accentuated by the use of current-day Persil boxes to hold information cards; Anon. 2006) spoke eloquently of the 60 years in which the original owners did not return and in which the German 
neighbours were reminded-if only periodically, when they went up into the atticof their non-return. The organizer of this exhibition was quoted by a local newspaper as saying: "Wir hoffen, dass auf vielen Dachböden des Dorfes noch solche Kartons mit wertvollen Spuren zu finden sind" ("We are hoping that many of the village's attics still contain such cardboard boxes with valuable traces of the past in them". Anon. 2006). For curators, such rediscoveries are bound to be a professional pleasure; however, factually they then deal with them.

One final point can be made about the Duldner family's table and chairs in Shanghai. Were the same furniture to be displayed in a German or Austrian museum, it would in all probability be used to expose a central contradiction in Nazi ideology: its ideological exclusion of Jews from the so-called Heimat culture (a culture of rootedness in place) in defiance of the fact that many Jews lived out that culture on a daily basis, not least through their choices of material objects such as folk furniture. The Jewish Museum of Franconia at Fürth (Jüdisches Museum Franken in Fürth) has a section devoted to Heimat which includes objects such as a tin of Nuremberg gingerbread - a classic culinary Heimat product-decorated with an image of the Nuremberg synagogue, which was a popular postcard motif in the early twentieth century. Like other contemporary Jewish museums, the Fürth museum emphasizes that before the Nazis drew an artificial dividing line between the Heimat and supposedly "internationalist" Judaism, most Jews and non-Jews experienced no such clear boundary. This is an important message for Germans and Austrians today because even if Jews played a full part in Heimat culture before 1933, they have played very little part in it since 1945 because rural Jewish communities were decimated in the Holocaust, so that the Nazis' artificial distinction has taken on a perverse kind of reality in the present.

This is not, however, the concern of the Shanghai museum, which presents the table and chairs as a generic example of foreign material culture, obviously nonChinese but not culturally contradictory or temporally layered. The chairs therefore demonstrate one way in which the meanings of objects are "lost in translation" when they move across borders to a new national context. This need not necessarily be accounted a loss. While it is not my intention to defend their triviality, the YouTube parodies of actor Bruno Ganz's rant—in his role as Hitler in the 2004 film Downfall (Der Untergang) — have shown that ignorance of another language or culture can create opportunities to generate new meanings. As Ganz is made to shout in one of the self-referential parodies that form a subset of this meme: "I should have done these rants in English. Then I would not have this parody problem. I should never have had these rants released with no subtitles" (Anon. 2009). The Duldner family's furniture, too, has been "released with no subtitles" in the sense that the home culture (the Duldners appear to have been Austrian) has no control over its interpretation in a new host culture. Yet the fact that German and Austrian Jews appear, in the Shanghai museum, as people who could and did unproblematically adopt the stereotypes of German folk style in their choice of furniture is potentially to be accounted a gain over German and Austrian museums, which have to patiently explain and re-assert the right of Jewish Germans and Austrians to appreciate the folk art and folk kitsch that have since come to be associated either with National Socialism or with a substantially non-Jewish post-war society. 


\section{Conclusion}

A longer account of the research presented here would certainly need to include photographs, which are increasingly displayed as objects, in photograph albums, folders, and storage boxes, to draw attention to their material role in the transmission of memory (good examples can be found at the German-Russian Museum, or Deutsch-Russisches Museum, in Berlin). In a longer account, I would also want to relate the use of household goods from the 1930s in history exhibitions to theories of object life cycles (the seminal work being Thompson 1979). Put in very general terms, museums profit from the "rubbish phase" of objects during which they lose value but survive, often unnoticed; what museums do not normally do is put that rubbish phase on display. Yet in the instances discussed here, that phase coincides with the "second history" of National Socialism from 1945 to the end of the century. Finally, in a longer presentation of the research, I would want to relate these examples to Assmann's study of the range of spatial metaphors-rooms and containers such as the attic and the (treasure) chest-that have been used since ancient times to conceptualize the workings of memory (Assmann 1999, 114-29; 161-62). I would show that, in this particular museum context, such containers do not just stand for memory (the locked box of our past, the attic of our mind); rather, they have been a real, practical agent in post-war German and Austrian remembering. The household objects studied here also fall clearly into Assmann's category of "passive forgetting" since they are "dispersed in forgotten depots" and "neglect[ed]" and "disregard[ed]" $(2010,99)$, yet a main argument in this article has been that the very "passivity" of this forgetting - the not quite throwing away of objects-also allows for intermittent remembering, both by the generation who experienced National Socialism and, indirectly, by those who grew up in these houses. In this, I follow Reiter, but whereas her work investigates remembering and forgetting, silence and communication, within the family home, I have discussed here what happens when that social activity is moved-necessarily in its materialized forms - out of real life and into the museum, to be contemplated by a national audience as a constituent part of their national past. Further study might consider what processes of distortion happen in that transfer process.

Open Access This article is distributed under the terms of the Creative Commons Attribution 4.0 International License (http://creativecommons.org/licenses/by/4.0/), which permits unrestricted use, distribution, and reproduction in any medium, provided you give appropriate credit to the original author(s) and the source, provide a link to the Creative Commons license, and indicate if changes were made.

\section{References}

Anon. 2006. Karton mit wertvollem Familienbesitz. Historisches Zeugnis vom bürgerlichen Selbstverständnis wohlhabender Landjuden in Memmelsdorf. Neue Presse Coburg, 14 October.

Anon. 2009. Hitler finds out about the Downfall parodies. YouTube https://www.youtube.com/watch?v= QSYk8ofhYFY. Accessed 30 Apr 2015.

Abt, J. 2006. The origins of the public museum. In A companion to museum studies, ed. S. Macdonald, 115-134. Oxford: Blackwell.

Arnold-de Simine, S. 2013. Mediating memory in the museum: Trauma, empathy, nostalgia. Basingstoke: Palgrave Macmillan. 
Assmann, A. 1999. Erinnerungsräume. Formen und Wandlungen des kulturellen Gedächtnisses. Munich: Beck.

Assmann, A. 2010a. Canon and archive. In A companion to cultural memory studies, ed. A. Erll, and A. Nünning, 97-107. de Gruyter: Berlin.

Assmann, A. 2010b. The holocaust-A global memory? Extensions and limits of a new memory community. In Memory in a global age: Discourses, practices and trajectories, ed. A. Assmann, and S. Conrad, 97-117. Basingstoke: Palgrave Macmillan.

Confino, A. 2006. Germany as a culture of remembrance: Promises and limits of writing history. Chapel Hill: The University of North Carolina Press.

Dean, M., C. Goschler, and P. Ther (eds.). 2007. Robbery and restitution: The conflict over Jewish property in Europe. New York: Berghahn.

Esposito, E. 2010. Social forgetting: A systems-theory approach. In A companion to cultural memory studies, ed. A. Erll, and A. Nünning, 181-189. Berlin: de Gruyter.

Fritsche, C., and J. Paulman (eds.). 2014. Arisierung" und "Widergutmachung” in deutschen Städten. Cologne: Böhlau.

Fuchs, A. 2008. Phantoms of war in contemporary german literature, films, and discourse: The politics of memory. Basingstoke: Palgrave Macmillan.

Gedenkstätte KZ-Osthofen. 2013. http://www.gedenkstaette-osthofen-rlp.de/index.php?id=52\&tx_ttnews \%5Btt_news\%5D=193\&cHash=0e7fc33f34404b11908e3108a56b3e75. Accessed 30 Apr 2015.

Gottfried, C. 2012. Vergraben, versteckt, verdrängt. Entnazifizierung am Beispiel der Kleidung. In LVRIndustriemuseum Ratingen, ed. Glanz und Grauen. Mode im "dritten Reich,76-77. Bönen/ Westfalen: Kettler.

Gray, P., and K. Oliver (eds.). 2004. The memory of catastrophe. Manchester: Manchester University Press.

Greiter, S. 2014. Flucht und Vertreibung im Familiengedächtnis. Geschichte und Narrativ. Munich: Herbert Utz.

Haerendel, U. 2004. Der Schutzlosigkeit preisgegeben. Die Zwangsveräußerung jüdischen Immobilienbesitzes und die Vertreibung der Juden aus ihren Wohnungen. In: "München arisiert". Entrechtung und Enteignung der Juden in der NS-Zeit, ed. Baumann A, and A. Heusler, 105-126. Munich: Beck.

Heckner, E. 2014. Affect, embodied memory, and the future of the museum. Unpublished contribution to the workshop "Emotional Strategies in Museum Exhibitions", held at the University of Bremen.

Hoelscher, S. 2006. Heritage. In A companion to museum studies, ed. Macdonald S. 198-218. Oxford: Blackwell.

Hooper-Greenhill, E. 2006. Studying visitors. In A companion to museum studies, ed. S. Macdonald, 362376. Oxford: Blackwell.

Huyssen, A. 2003. Memory sites in an expanded field: The memory park in Buenos Aires. Present pasts. Urban palimpsests and the politics of memory, 94-109. Stanford: Stanford University Press.

Köhlmeier, M. 2008. Der Silberlöffel. In Heimat Diaspora. Das Jüdische Museum Hohenems, ed. H. Loewy. 252-255. Hohenems: Bucher. English translation: The silver spoon. In At home/diaspora: The Jewish museum hohenems, ed. H. Loewy, trans. by Judith Hayward, 252-254. Hohenems: Bucher.

Kreps, C. 2006. Non-western models of museums and curation in cross-cultural perspective. In $A$ companion to museum studies, ed. S. Macdonald, 457-472. Oxford: Blackwell.

Levy, D., and N. Sznaider. 2006. The holocaust and memory in the global age. Trans. by Assenka Oksiloff. Philadelphia: Temple University Press.

Loewy, H. 2012. Diasporic home or homelessness: The museum and the circle of lost and found. German historical institute London bulletin. XXXIV, 1 (May 2012): 41-58.

Logan, W., and K. Reeves (eds.). 2009. Places of pain and shame: Dealing with difficult heritage. Abingdon: Routledge.

Macdonald, S. 2009. Difficult heritage: Negotiating the nazi past in nuremberg and beyond. Abingdon: Routledge.

Macdonald, S. 2013. Memorylands: Heritage and identity in Europe. London: Routledge.

Meinl, S., and J. Zwilling. 2004. Legalisierter Raub. Die Ausplünderung der Juden im Nationalsozialismus durch die Reichsfinanzverwaltung in Hessen. Frankfurt and New York: Campus.

Neumann, V. 1999. Nicht der Rede wert. Die Privatisierung der Kriegsfolgen in der frühen Bundesrepublik. Lebensgeschichtliche Erinnerungen. Münster: Verlag Westfälisches Dampfboot. 
NS-Dokumentationszentrum der Stadt Köln. 2001. http://www.museenkoeln.de/nsdok/fundstuecke/. Accessed 30 Apr 2015.

NS-Dokumentationszentrum der Stadt Köln. 2013. http://www.museenkoeln.de/ns-dokumentations zentrum/default.aspx?s=494. Accessed 30 Apr 2015.

Reichel, P., H. Schmid, and P. Steinbach (eds.). 2009. Der Nationalsozialismus-Die zweite Geschichte. Überwindung-Deutung-Erinnerung. Bonn: C. H. Beck.

Reiter, M. 2006. Die Generation danach. Der Nationalsozialismus im Familiengedächtnis. Innsbruck: Studien Verlag.

Rogalski, U. 2014. Ein ganzes Leben in einer Hutschachtel. Geschichten aus dem Leben der jüdischen Innenarchitektin Bertha Sander 1901-1990. Hamburg: Marta Press.

Rothberg, M. 2009. Multidirectional memory: Remembering the holocaust in the age of colonization. Stanford: Stanford University Press.

Shanghai Jewish Refugees Museum. 2014. http://www.shanghaijews.org.cn/english/article/?sid=2. Accessed 30 Apr 2015.

Stiftung Jüdisches Museum Berlin and Stiftung Haus der Geschichte der Bundesrepublik Bonn, eds. 2006. Heimat und Exil. Emigration der deutschen Juden nach 1933. Frankfurt: Jüdischer Verlag.

Summers, J. 2015. Fashion on the ration: Style in the Second World War. London: Profile Books.

Thompson, M. 1979. Rubbish theory: The creation and destruction of value. Oxford: Oxford University Press.

Verhoeven, M. 1990. Das schreckliche Mädchen (The Nasty Girl). Film (Germany).

Verhoeven, M. 2008. Menschliches Versagen (Human Failure). Film (Germany).

Welzer, H., S. Moller, and K. Tschuggnall. 2002. Opa war kein Nazi. Nationalsozialismus und Holocaust im Familiengedächtnis. Frankfurt: Fischer.

Williams, P. 2007. Memorial museums: The global rush to commemorate atrocities. Oxford: Berg.

Chloe Paver, Dphil Oxon. is Associate Professor of German at the University of Exeter, UK. She has written extensively on the role played by history museums in wider processes of cultural memory formation in Germany and Austria. 